\title{
Jazykové potřeby zahraničních lékařů pracujících v českých nemocnicích
}

\author{
Jitka Cvejnová
}

\begin{abstract}
Abstrakt: Vedle zahraničních lékařů, kteří vystudovali v ČR lékařské obory, působí nyní v České republice zahraniční lékaři, kteří zde nestudovali především ze zemí bývalého Sovětského svazu. Tito lékaři musí jednak zvládnout lékařskou praxi v nemocnicích, jednak náročné aprobační zkoušky České lékařské komory. Nezbytnou součástí jejich pracovního úspěchu je ovládnutí poměrně rozsáhlé škály řečových dovedností v češtině.

Cílem příspěvku je analyzovat jazykové potřeby těchto lékařů v jednotlivých řečových dovednostech pomocí deskriptorů a představit jednotlivé deskriptory tak, aby je bylo možné využít pro tvorbu tzv. modelových scénářů pro výuku lékařů, a to i s ohledem na skutečnost, že se v poslední době výuka podle modelových scénářủ prosazuje jako jedna ze základních metod výuky jazyka v pracovní oblasti.
\end{abstract}

Klíčová slova: jazykové potřeby, řečové dovednosti - modelové scénáře, zahraniční lékaři čeština jako druhý jazyk

\begin{abstract}
Besides the foreign doctors who have studied medical disciplines in the Czech Republic, there are now foreign doctors in the Czech Republic who have not studied here, coming mainly from the countries of the former Soviet Union. These doctors have to manage the medical practice in hospitals as well as demanding certification examinations of the Czech Medical Chamber.

The aim of the paper is to analyze the language needs of these doctors in individual language skills using descriptors and to present the individual descriptors so that they can be used to create so-called model scenarios for teaching, also with regard to the fact that the scenarios are one of the basic methods of language teaching in the work area these days.
\end{abstract}

Key words: language needs, language skills, model scenarios, foreign doctors, Czech as a second language

Národní ústav pro vzdělávání je garantem zkoušek pro trvalý pobyt a zároveň výuky češtiny jako druhého jazyka, a to jak pro děti, tak pro dospělé. Ústav touto svou činností naplňuje cíle Koncepce pro integraci cizinců (jde o usnesení vlády, které publikuje vláda vždy v měsíci lednu, koncept je přístupný na webových stránkách Ministerstva vnitra), která je hlavním dokumentem, o který se v České republice opírá jazyková politika vůči cizincům z tzv. třetích zemí.

Pojem druhý jazyk byl zaveden podle zahraničních vzorů, a i když jej různí autoři vymezují poněkud odlišně, ukazuje vždy na jazykové vzdělávání osob s tzv. migračním pozadím. Vyjdeme-li z definice migranta, kterou na základě shody členských států OSN aplikuje tato instituce ke statistickým účelům, pak migrantem je „každá osoba, jež si zvolila určitou zemi jako místo svého obvyklého pobytu na 
dobu delší než rok“ (ONU, 1998) Tato definice migranta vede přirozeně k tomu, že za uživatele druhého jazyka lze považovat všechny osoby, které v určité zemi dlouhodobě žijí, a to včetně př́slušníků jejich rodin, nebot' se všichni musí v různé míře vyrovnávat $\mathrm{s}$ jazykem, kterým se $\mathrm{v}$ této zemi převážně komunikuje. Z politických důvodů se $\mathrm{v}$ České republice státní jazyková politika zaměřuje jen na osoby pocházející z tzv. třetích zemí, tj. zemí mimo Evropský hospodářský prostor.

Rozlišování cizího jazyka a druhého jazyka má význam především didaktický, ukazuje na odlišný přístup $\mathrm{k}$ obsahu učiva i metodám jazykové výuky. Osobně vnímám rozdíl mezi cizím a druhým jazykem pro češtinu takto: Výuka češtiny jako cizího jazyka je př́ípravou na potenciální situace, do kterých se osoba učící se jazyk může dostat, ale které nutně nemusejí nastat. Výuka češtiny jako druhého jazyka je prŕípravou na konkrétní situace reálného života, do nichž se migrant nevyhnutelně dostane (Škodová a Cvejnová, 2017).

Jednou ze specifických skupin uživatelů češtiny jako druhého jazyka jsou zahraniční lékaři, kteří medicínu v České republice nevystudovali, ale přicházejí do České republiky pracovat. Tato skupina se musí připravit jednak na vysoké požadavky ohledně jazykových znalostí, které by v ideálním př́ipadě měly odpovídat úrovni C1 Společného evropského referenčního rámce, jednak na náročné aprobační zkoušky. Jazykové znalosti zahraničních lékařu se neověřují specifickou zkouškou, ale ověřují se nepřímo prostřednictvím aprobační zkoušky, která má 3 části: 1) písemný test, jenž se skládá z odborného testu a testu znalostí týkajících se systému zdravotnictví a základů práva ve vztahu $\mathrm{k}$ poskytování zdravotních služeb v České republice 2) praktickou část, jež zahrnuje př́pravu 5 případových studií a 3) ústní část, kdy se prověřují odborné znalosti uchazeče a kdy uchazeč obhajuje jednu z připravených př́padových studií (viz příslušné webové stránky Ministerstva zdravotnictví).

Z výše uvedeného vyplývá, že se zahraniční lékaři potřebují na svou práci v České republice důkladně jazykově připravit. Většina z nich už přichází s určitou znalostí ze své země, ale žádný určitě nepřichází s tak vysokou, jaká je potřebná k zvládnutí aprobační zkoušky. Lékařum jsou nabízeny různé jazykové kurzy, eventuálně se mohou vzdělávat samostudiem. Nejvíc je dle nabídky propracován kurz ÚJOP (viz www této organizace), jeho intenzivní kurz spojuje terminologickou př́ípravu a studium obecného jazyka. Kurz je nicméně poněkud finančně náročný (3830 eur) a trvá po dobu 10 měsíců, která je poměrně dlouhá. Kurz těží ze znalosti př́pravy zahraničních studentů ke studiu medicíny, které na této instituci trvá bezmála již 50 let. Je však třeba si zároveň položit otázku, zda cíle pregraduálních studentů a již vystudovaných lékařủ jsou opravdu vždy shodné. Vedle ÚjOP jsou nabízeny i kurzy komerční, které vyžadují již předběžné jazykové znalosti (minimálně úroveň A1). Tyto kurzy jsou zaměřeny převážně terminologicky, oproti kurzům na ÚJOP jsou kratší, trvají jeden semestr, a proto jsou také levnější. 
Mnozí lékaři nastupují jako stážisté v nemocnicích, takže nemohou navštěvovat žádné intenzivní kurzy, ale spíše kurzy večerní nebo odpolední, někteří volí kurzy individuální, jiní skupinové. Někteří se připravují i pomocí moderních technologií a využívají on-line kurzy Masarykovy univerzity https://mluvtecesky.net, kde se mohou seznámit s terminologií. Podobný on-line kurz nabízí také Fakulta sociálních studií Jihočeské univerzity pod názvem Interkulturní zdravotnická komunikace v Evropě na adrese http:/imed.com.jcu.cz. Konečně někteří volí pouze učebnici, a to nejčastěji titul Mokrošová a kol. Lékařská čeština (2006).

V poslední době se ve výuce migrantů, ale např́íklad i ve výuce odborného jazyka začala využívat metoda modelových scénářů (Grünhage-Monetti a kol., 2004) Tato metoda vychází z důkladného zmapování jazykových potřeb uživatelů jazyka a vytvoření individualizovaných scénářů pro konkrétní kurzy. Uplatnění modelových scénářů umožňuje spojit jazykovou výuku s reálným světem. Modelové scénáře představují začlenění určitých modelových situací z praxe přímo do jazykového vyučování, studující se učí konkrétnímu jazykovému chování. Scénáře umožňují zahrnout obecné znalosti, sociokulturní prvky, řečové dovednosti, jazykové funkce a jazykové prostředky. Umožňují vidět nejen „makro“ pohled, ale také „mikro“ pohled na jednotlivé součásti jazykové komunikace. Jsou to nástroje, které umožňují definovat, vyučovat, ale i posuzovat dovednosti studujících (North a kol., 2016).

Velmi důležitou fází vytváření modelových scénářů je mapování jazykových potřeb studujících. Je to první fáze, která vede k vytvoření vhodného modelového scénáře, tedy vhodného obsahu kurzu. Zejména ve specifických kurzech, jako jsou kurzy pro lékaře, je důležité zjistit, co frekventanti skutečně potřebují, nikoliv to, co si tvůrci kurzů myslí, že frekventanti potřebují.

Analýzu potřeb jsme rozdělili do dvou etap. V první etapě jsme hovořili s absolventy kurzů a zjištovali jsme jejich názory na absolvované kurzy jazyka, eventuálně jejich připomínky $\mathrm{k}$ absolvovaným kurzům. Ve druhé části jsme předložili vytipované fokusní skupině dotazník, který jsme vypracovali na základě rozhovorů s absolventy kurzů a koncipovali jsme ho nikoliv tematicky, jak je běžné ve výuce odborného jazyka, kdy se zjišt'ují profilová témata, ale zjištóovali jsme profilové dovednosti. Předvýběr těchto dovedností byl proveden na základě rozhovorů v první etapě.

Při rozhovorech se ukázalo, že kurzy jsou správně zaměřeny na absolvování aprobační zkoušky, přičemž vycházejí ze zkušeností přípravy k přijímacím zkouškám. Některé předkládané texty jsou z hlediska obsahu viditelně zaměřeny na zdravotnických personál, eventuálně na pregraduální studenty. Tím, že se výuka zaměřuje spíše na složení aprobační zkoušky, nevěnuje se skutečným potřebám lékařské praxe, například se vůbec nenacvičuje telefonování, které je jedním z nejčastějších prostředků komunikace v rámci jednotlivých oddělení v nemocnicích a které, jak dotazovaní potvrdili, představuje zpočátku pro ně určitý problém. Lékaři se 
rovněž málo seznamují s obecnou češtinou, kterou pacienti běžně mluví. $\mathrm{V}$ kurzu se setkávají pouze se spisovným jazykem. Velmi málo se čtou texty zaměřené jinak než na odbornou lékařskou terminologii a odborný styl. Pomíjí se fakt, že druhá část písemného testu obsahuje texty zákonů, nařízení a vyhlášek a že tuto speciální terminologii lékaři potřebují také $\mathrm{v}$ rámci př́ípravy na aprobační zkoušku zvládnout. Příslušné lexikum navíc není probíráno ani v on-line kurzech, ani $\mathrm{v}$ učebnicích.

Bylo zamýšleno, že dotazník bude zadán pouze úspěšným absolventům aprobační zkoušky. Vzhledem k tomu, že aprobační zkoušky nezvládá 85 \% až 90 \% uchazečů, tak bylo velmi obtížné najít řádně pracující lékaře v nemocnicích, kteří zvládli zkoušku. Podařilo se najít celkem 5 lékařu (4 muže a 1 ženu), k nim se připojil $\mathrm{v}$ dotazníku ještě jeden muž, kterému aprobační zkouška unikla o 1 bod a u něhož je značný předpoklad, že bude při dalším pokusu úspěšný. Všichni lékaři pracují skutečně v České republice, řada tzv. aprobovaných lékařu v ČR totiž po absolvování zkoušky v zemi nezůstává a hledá si práci v Německu. V Německu aprobační zkoušku vykonanou v ČR uznávají, takže v Německu se potom už soustřed'ují jen na získání znalostí z němčiny. $\mathrm{V}$ rámci možností se podařilo zajistit i profesně pestrou skupinu aprobovaných lékařů, kterou tvoři 3 chirurgové, 1 ortopéd, 1 anesteziolog a 1 gynekoložka. Neúspěšným absolventem je ortopéd.

Výsledky dotazníkového šetření jsou v tab. 1-5.

Na základě obou provedených etap šetření bylo možné stanovit tyto jazykové potřeby lékařů $\mathrm{v}$ rámci jednotlivých dovedností.

- Čtení lékařská dokumentace, odborné texty, právní texty, administrativně správní dokumenty, e-maily, komunikace na sociálních sítích

- Poslech hlášení v nemocnici, získávání informací po telefonu

- Mluvení přímé a telefonické rozhovory s pacienty, jejich př́buznými, se sestrami, dalším zdravotnickým personálem (rentgen, laboratoř, záchranka), $\mathrm{s}$ primářem a dalšími nadřízenými,rozhovory s policií a úředními osobami při výkonu práce

- Psaní lékařská dokumentace, úřední zprávy, vzkazy na oddělení, písemná komunikace s cizineckou policií a OAMP

- Mediace vysvětlování diagnózy, postupů léčby, vysvětlování rizik spojených s chirurgickým zásahem, užíváním léků, očkováním

\section{Závěr}

Výše uvedené potřeby stanovené na základě provedené analýzy by měly tvořit základní osnovu pro př́pravu modelových scénářů, které naleznou využití v jazykových kurzech češtiny pro zahraniční lékaře. Tučně byly zvýrazněny zejmé- 
Tab. 1: Dovednost čtení

\begin{tabular}{|c|c|c|c|c|c|c|}
\hline & Chirurg 1 & Chirurg 2 & Chirurg 3 & Ortoped & Anesteziolog & Gynekol. žena \\
\hline \multicolumn{7}{|l|}{ Čtení } \\
\hline $\begin{array}{l}\text { Odborné knihy } \\
\text { (monografie) z oboru } \\
\text { specializace }\end{array}$ & + & + & + & + & + & + \\
\hline $\begin{array}{l}\text { Jiné odborné knihy } \\
\text { (event. které možno } \\
\text { doplnit do části } \\
\text { Poznámky) }\end{array}$ & + & + & + & + & + & \\
\hline $\begin{array}{l}\text { Právní texty } \\
\text { (např. zákony, } \\
\text { nařízení, vyhlášky) }\end{array}$ & + & + & + & + & + & + \\
\hline $\begin{array}{l}\text { Všeobecné novinové } \\
\text { / internetové články }\end{array}$ & & málokdy & + & + & + & + \\
\hline $\begin{array}{l}\text { Novinové/internetové } \\
\text { články se zdravotní } \\
\text { tematikou (ne } \\
\text { odborné) }\end{array}$ & + & + & + & + & + & + \\
\hline $\begin{array}{l}\text { Články v odborných } \\
\text { časopisech / na } \\
\text { odborných serverech }\end{array}$ & + & + & + & + & + & + \\
\hline $\begin{array}{l}\text { Lékařské zprávy } \\
\text { pacientů }\end{array}$ & + & + & + & + & + & + \\
\hline Recepty pro pacienty & + & + & + & & + & + \\
\hline $\begin{array}{l}\text { Poučený souhlas } \\
\text { pacientů }\end{array}$ & + & + & + & + & + & + \\
\hline $\begin{array}{l}\text { Lékařská } \\
\text { dokumentace } \\
\text { pacientů }\end{array}$ & + & + & + & + & + & + \\
\hline $\begin{array}{l}\text { Úřední dokumenty } \\
\text { v běžném životě } \\
\text { (např. rodný list, } \\
\text { úmrtní list, } \\
\text { průkazy ...) }\end{array}$ & + & + & + & + & + & + \\
\hline $\begin{array}{l}\text { Písemná konverzace } \\
\text { na facebooku/skypu }\end{array}$ & & + & & & + & + \\
\hline E-maily od kolegů & & & & & + & + \\
\hline \multicolumn{7}{|l|}{ E-maily od pacientů } \\
\hline $\begin{array}{l}\text { E-maily od správně } \\
\text { technického } \\
\text { personálu }\end{array}$ & + & + & + & & + & + \\
\hline
\end{tabular}

\section{Poznámky:}

Ch 1 hodně používal zdrav. zákony 372/2011, 374/2011, 373/2011

Ch 2 Krásná literatura

Ch 2 Zprávy na facebooku 
Tab. 2: Dovednost poslechu

\begin{tabular}{|c|c|c|c|c|c|c|}
\hline & Chirurg 1 & Chirurg 2 & Chirurg 3 & Ortoped & Anesteziolog & Gynekol. žena \\
\hline \multicolumn{7}{|l|}{ Poslech } \\
\hline Hlášení v nemocnici & + & + & + & + & + & + \\
\hline Zprávy na záznamníku & & & & + & + & \\
\hline \multicolumn{7}{|l|}{ Zprávy na whatsappu } \\
\hline $\begin{array}{l}\text { Pokyny telefonního } \\
\text { automatu }\end{array}$ & & málokdy & + & + & + & + \\
\hline Rozhlasové informace & & + & + & + & + & + \\
\hline $\begin{array}{l}\text { Rozhlasové programy } \\
\text { se zdravotní } \\
\text { tematikou }\end{array}$ & + & & + & + & + & + \\
\hline Televizní informace & & + & + & + & + & + \\
\hline $\begin{array}{l}\text { Televizní programy se } \\
\text { zdravotní tematikou }\end{array}$ & & sporadicky & + & + & + & \\
\hline
\end{tabular}

Poznámky:

Ch 2 Poslech hlášení v obchodech, na ulici atd.

na potřeby, s nimiž dosavadní kurzy dosud nepočítaly, nebo s nimi počítaly jen okrajově. Jedná se o např́klad o četbu zdravotnických předpisů, kterou jsou podstatnou součástí aprobačních testů. Jiným důležitým a opomíjeným okruhem je práce se správně administrativními texty, s nimiž lékaři přicházejí do styku. Lékaři nejen musí takovým dokumentům rozumět, ale musí se je sami naučit vytvářet, a to, pokud možno, bez větší chybovosti. Větší pozornost je dále třeba věnovat i nácviku telefonování, které se jeví hlavním komunikačním prostředkem v rámci jednotlivých pracovišt'. Telefonickou konverzaci, která na rozdíl od př́mé konverzace, neprobíhá s vizuální oporou, je třeba samostatně nacvičovat. Konečně nelze zanedbávat ani mediační rovinu, zejména předávání diagnózy pacientům a vysvětlování rizik spojených s různými lékařskými zákroky.

Ukazuje se, že jednotlivé modelové scénáře kurzů zaměřené na př́ípravu lékařů $\mathrm{k}$ aprobační zkoušce by měly odrážet všechny popsané potřeby $\mathrm{v}$ rámci jednotlivých dovedností. Velmi žádoucí by bylo, aby lékaři prošli v první etapě obecnou jazykovou př́pravou a v druhé etapě výukou vycházející z jednotlivých modelových scénářù, které zohlední popsané potřeby. $\mathrm{V}$ rámci této druhé etapy by měla být věnována pozornost i obecné češtině, a to zejména při nácviku poslechu a mluvení tak, aby si lékaři zvykli na rozdíl mezi psanou a mluvenou češtinou a naučili se $\mathrm{s}$ tímto rozdílem aktivně pracovat.

\section{Literatura}

Cadre européen commun de référence pour les langues: apprendre, enseigner, évaluer. Volume complémentaire avec de nouveaux descripteurs. (2018). Strasbourg: Conseil de l'Europe. 
Tab. 3: Dovednost mluvení

\begin{tabular}{|c|c|c|c|c|c|c|}
\hline & Chirurg 1 & Chirurg 2 & Chirurg 3 & Ortoped & Anesteziolog & Gynekol. žena \\
\hline \multicolumn{7}{|l|}{ Mluvení } \\
\hline $\begin{array}{l}\text { Přímý rozhovor } \\
\text { s pacientem }\end{array}$ & + & + & + & + & + & + \\
\hline $\begin{array}{l}\text { Přímý rozhovor } \\
\text { s pacientovými } \\
\text { príbuznými }\end{array}$ & + & + & + & + & + & + \\
\hline $\begin{array}{l}\text { Přímý rozhovor se } \\
\text { sestrou }\end{array}$ & + & + & + & + & + & + \\
\hline $\begin{array}{l}\text { Přímý rozhovor } \\
\text { s dalším } \\
\text { zdravotnickým } \\
\text { personálem } \\
\text { (záchranka, laboratoř, } \\
\text { rentgen) }\end{array}$ & + & + & + & + & + & + \\
\hline $\begin{array}{l}\text { Přímý rozhovor } \\
\text { s kolegy }\end{array}$ & + & + & + & + & + & + \\
\hline $\begin{array}{l}\text { Přímý rozhovor } \\
\text { s primářem a dalšími } \\
\text { nadřízenými }\end{array}$ & + & + & + & + & + & + \\
\hline $\begin{array}{l}\text { Telefonický rozhovor } \\
\text { s pacientem }\end{array}$ & + & + & + & + & + & + \\
\hline $\begin{array}{l}\text { Telefonický rozhovor } \\
\text { s pacientovými } \\
\text { príbuznými }\end{array}$ & + & + & + & + & + & + \\
\hline $\begin{array}{l}\text { Telefonický rozhovor } \\
\text { se sestrou }\end{array}$ & + & + & + & + & + & + \\
\hline $\begin{array}{l}\text { Telefonický rozhovor } \\
\text { s dalším } \\
\text { zdravotnickým } \\
\text { personálem } \\
\text { (záchranka, laboratoř, } \\
\text { rentgen) }\end{array}$ & + & + & + & + & + & + \\
\hline $\begin{array}{l}\text { Telefonický rozhovor } \\
\text { s kolegy }\end{array}$ & + & + & + & & + & + \\
\hline $\begin{array}{l}\text { Telefonický rozhovor } \\
\text { s primářem a dalšími } \\
\text { nadřízenými }\end{array}$ & + & + & + & & + & + \\
\hline $\begin{array}{l}\text { Namluvení zprávy na } \\
\text { záznamník/whatsapp }\end{array}$ & & & & + & & \\
\hline $\begin{array}{l}\text { Podání odborného } \\
\text { názoru / podání } \\
\text { svědectví }\end{array}$ & & + & & + & & \\
\hline $\begin{array}{l}\text { Odborná prezentace } \\
\text { (např. power- } \\
\text { pointová) }\end{array}$ & & & & + & & \\
\hline
\end{tabular}

Poznámky:

$\mathrm{G}$ besedy s budoucími maminkami, školení budoucích maminek, cvičení s budoucími maminkami 
Tab. 4: Dovednost psaní

\begin{tabular}{|c|c|c|c|c|c|c|}
\hline & Chirurg 1 & Chirurg 2 & Chirurg 3 & Ortoped & Anesteziolog & Gynekol. žena \\
\hline \multicolumn{7}{|l|}{ Psaní } \\
\hline Lékařská zpráva & + & +++ & + & + & + & + \\
\hline Recept & + & + & + & + & + & + \\
\hline $\begin{array}{l}\text { Zápis do } \\
\text { dokumentace } \\
\text { (např. při vizitě) }\end{array}$ & + & + & + & + & + & + \\
\hline $\begin{array}{l}\text { Úřední zprávy } \\
\text { (např. informace pro } \\
\text { policii, matriku, ...) }\end{array}$ & + & + & + & + & + & + \\
\hline Vzkazy na oddělení & + & + & + & & + & + \\
\hline $\begin{array}{l}\text { Korespondence } \\
\text { s pacientem }\end{array}$ & & & & + & + & \\
\hline $\begin{array}{l}\text { Korespondence } \\
\text { s pacientovými } \\
\text { příbuznými }\end{array}$ & & & & + & & \\
\hline $\begin{array}{l}\text { Korespondence se } \\
\text { zdravotnickým } \\
\text { personálem }\end{array}$ & & & & + & + & \\
\hline $\begin{array}{l}\text { Korespondence } \\
\text { s kolegy }\end{array}$ & & & + & + & + & \\
\hline $\begin{array}{l}\text { Korespondence } \\
\text { s primářem a dalšími } \\
\text { nadřízenými }\end{array}$ & & + & + & & + & \\
\hline $\begin{array}{l}\text { Korespondence } \\
\text { prostřednictvím } \\
\text { sociálních sítí } \\
\text { (např. facebook) }\end{array}$ & & + & & & + & + \\
\hline \multicolumn{7}{|l|}{$\begin{array}{l}\text { Písemná příprava } \\
\text { referátu }\end{array}$} \\
\hline $\begin{array}{l}\text { Písemná příprava } \\
\text { odborné prezentace }\end{array}$ & & $\begin{array}{l}\text { ojedinělé } \\
\text { případy }\end{array}$ & & + & & \\
\hline
\end{tabular}

Poznámky:

Ch 1 Hodně měl korespondence s cizineckou policií

Ch 2 Korespondence s policií, ministerstvem, e-shopem

GrünhageMonetti, M., Hallenwinjet, E., Holland, Ch. (2004). Second language at the workplace. Strasbourg: Conseil de l’Europe.

IMED [online]. [vid. 2019-14-1]. Dostupné z: http://imed.com.jcu.cz

Ministerstvo zdravotnictví [vid. 2019-14-1]. Dostupné z https://www.mzcr.cz/dokumenty/aprobacnizkousky_1784_952_3.html.

Ministerstvo vnitra [vid. 2019-14-1]. Dostupné z https://www.mvcr.cz/migrace/clanek/ integrace-cizincu.aspx?q=Y2hudW09Mg\%3D\%3D

Mluvtecesky.net [vid. 2019-14-1] Dostupné z https://mluvtecesky.net. Konzultováno 14. ledna 2019 
Tab. 5: Mediace

\begin{tabular}{|c|c|c|c|c|c|c|}
\hline & Chirurg 1 & Chirurg 2 & Chirurg 3 & Ortoped & Anesteziolog & Gynekol. žena \\
\hline \multicolumn{7}{|l|}{ Mediace } \\
\hline $\begin{array}{l}\text { Vysvětlení problémů } \\
\text { spojených } \\
\text { s diagnózou }\end{array}$ & + & + & + & + & + & + \\
\hline $\begin{array}{l}\text { Vysvětlení rizik } \\
\text { spojených } \\
\text { s očkováním }\end{array}$ & + & & & + & + & + \\
\hline $\begin{array}{l}\text { Vysvětlení rizik } \\
\text { spojených } \\
\text { s chirurgickým } \\
\text { zásahem }\end{array}$ & + & + & + & + & + & + \\
\hline $\begin{array}{l}\text { Vysvětlení rizik } \\
\text { spojených s užíváním } \\
\text { léků }\end{array}$ & + & + & + & + & + & + \\
\hline
\end{tabular}

Poznámky:Bez poznámek

North, B, Ortega, A., Sheehan, S. (2016). Core Inventory for General English [online]. British Council / Eaquals, s. 13. Dostupné z: http://eaquals.org.

Scénarios d'apprentissage et d'enseignement des langues pour les migrants adultes Conseil de l'Europe / Unité des Politiques linguistiques (Strasbourg) - Projet ILMA [online]. Dostupné z: www.coe.int/langmigrants/fr, konzultováno: 28. 11. 2016.

ŠKodová, S. A Cvejnová, J. (2017): Jazyková integrace a komunikace s cizinci (úroveň A2). První vydání. Praha: Národní ústav pro vzdělávání, školské poradenské zařízení a zařízení pro další vzdělávání pedagogických pracovníků.

ÚJOP UK [vid. 2018-10-1]. Dostupné z http://ujop.cuni.cz/kurzy/kurzy-cestiny-pro-lekare-cizince. Konzultováno dne 1. října 2018

\section{Autorka}

\section{Mgr. Jitka Cvejnová}

Vystudovala obor francouzský jazyk - španělský jazyk - český jazyk na Filozofické fakultě Masarykovy univerzity v Brně. Vyučovala češtině pro cizince na ve Studijním středisku v Dobrušce UJOP UK a pracovala jako metodička tohoto střediska. Později byla ředitelkou Studijního střediska v Dobrušce. Působila rovněž jako lektorka češtiny na Univerzitě Paris IV - Sorbonne. Po návratu pracovala jako odborná asistentka oddělení češtiny Ústavu jazykové a odborné přípravy Univerzity Karlovy v Praze a vyučovala francouzštinu a španělštinu na Fakultě informatiky a managementu Univerzity v Hradci Králové. V současné době je koordinátorkou zkoušky z češtiny pro trvalý pobyt na Národním ústavu pro vzdělávání a konzultantkou různých projektů češtiny pro cizince.

e-mail: cvejnovajitka55@gmail.com 